\title{
Antioxidant capacity and contents of phenols, ascorbic acid, $\beta$-carotene and lycopene in lettuce
}

\author{
Jasmina M. Zdravkovići ${ }^{1}$ Gordana S. Aćamović-Djoković ${ }^{2}$, Jelena D. Mladenović ${ }^{2}$, Radoš M. Pavlović ${ }^{2}$, \\ Milan S. Zdravković ${ }^{1}$ \\ ${ }^{1}$ Institute for Vegetable Crops, Smederevska Palanka, Serbia \\ ${ }^{2}$ Faculty of Agronomy, University of Kragujevac, Serbia
}

\begin{abstract}
The antioxidant activity of three lettuce varieties (Lactuca sativa L.) Emerald, Vera and Neva, cultivated in two kinds of protected spaces, a glasshouse and a plastic greenhouse, under controlled conditions, was determined. The content of antioxidant compounds: total phenols, flavonoids, L-ascorbic acid, $\beta$-carotene and lycopene, were determined in ethanolic extracts of the lettuce with spectrophotometric methods. The largest content of total phenols ( $78.98 \pm 0.67 \mathrm{mg} \mathrm{GAE} / \mathrm{g}$ of dry extract) was found in ethanolic extract of the lettuce variety Neva cultivated in a plastic greenhouse, whereas the largest content of flavonoids $(35.45 \pm 0.95 \mathrm{mg} \mathrm{RU} / \mathrm{g}$ of dry extract) was displayed in the lettuce Emerald cultivated in a glasshouse. It was observed that the lettuce cultivated in the glasshouse contained a somewhat higher content of L-ascorbic acid than the lettuce same variety from plastic greenhouse. The content of lycopene in the examined lettuce is negligible, and the content of $\beta$-carotene is low. On the other hand, the high content of phenolic components causes favourable antioxidant properties found in all varieties of examined lettuce.
\end{abstract}

Keywords: lettuce, antioxidant, phenolics, ascorbic acid, beta-carotene, lycopene.

SCIENTIFIC PAPER

UDC 635.52:66:54

Hem. Ind. 68 (2) 193-198 (2014)

doi: 10.2298/HEMIND130222043Z

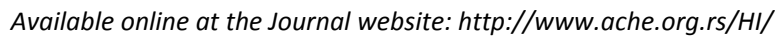

The formation of free radicals is related to the normal metabolism of aerobic cells. The consummation of oxygen typical during the growth of cells leads to the formation of a series of oxygenic free radicals. The interaction of these free radicals with the molecules of lipidic nature produces new radicals, hydroperoxides and different peroxides [1-3]. This group of radicals (superoxide, hydroxyl and lipid peroxides) can react with biological systems in a cytotoxic manner. It was shown that flavonoids and phenols display an important antioxidant activity towards these radicals, which is generally based on the redox properties of their phenolic hydroxyl groups [4-6]. The phenolic components inactivate the lipid free radicals and prevent the dissolution of hydroperoxides to the free radicals [7]. It is believed that free radicals and their uncontrolled products are one of the important causes of the development of some pathogenic processes such as prostate and colon cancers [8] and coronary heart diseases [9].

Over the last years the doubt regarding the toxicity of certain synthetic compounds used in nutrition has increased, and therefore the interest in natural products has also grown $[10,11]$. With this aim, researchers consider the possibilities of isolating bioactive compounds from natural products by extraction and puri-

Correspondence: J.M. Zdravković, Institute for Vegetable Crops, Karađorđeva 71, Smederevska Palanka, Serbia.

E-mail: jzdravkovic@institut-palanka.co.rs

Paper received: 22 February, 2013

Paper accepted: 10 June, 2013 fication. Antioxidant compounds can scavenge free radicals and therefore slow the processes of lipid peroxidation, which is one of the main reasons for deterioration of food products during processing and storage [12]. Thus, over the course of recent years, the interest in replacing the synthetic antioxidants with natural antioxidants, especially those of plant origin, has been growing [13].

Vegetables and fruits are rich sources of antioxidants such as vitamins $A, C$ and $E$, carotenoids, polyphenolic compounds and flavonoids [14], which prevent the attack of free radicals decreasing the risk of chronic diseases. It is believed that the consumption of dietary antioxidants from natural sources serves as a good prevention of cardiovascular diseases especially atherosclerosis [15]. Antioxidant properties of different sorts of vegetables are being increasingly researched in fundamental science, as well as in food industry with the aim of determining the nutritive values of vegetables and protecting the human health.

Lettuce (Lactuca sativa L.) belongs to the family Asteraceae and it is the most popular leaf vegetable consumed in increasingly greater amounts because of its nutritive values [16], as well as the fact that it is used fresh so that all the ingredients remain intact. Lettuce is used almost throughout the year since there are a number of varieties which are successfully cultivated in early spring, during the summer and winter. In everyday nutrition lettuce is of great significance primarily for its content of biologically active substances, especially phenolic compounds, ascorbic acid, vitamins 
$A$ and $\mathrm{K}$, folates and carotenoids [17]. The nutritive content varies depending on the lettuce type $[18,19]$.

The aim of this paper has been to determine the content of antioxidant components (total phenols, flavonoids, L-ascorbic acid, $\beta$-carotene and lycopene) and antioxidant activity of three lettuce varieties.

\section{EXPERIMENTAL}

\section{Plant material}

The research included three different varieties of lettuce (Lactuca sativa L.); two domestic varieties, Vera and Neva, the selection was made by the Institute for Vegetable Crops, Smederevska Palanka, and the variety Emerald, originating from the Netherlands. All lettuce varieties are head-forming types, type Butterhead, green-leafed, intended for cultivation during winter. The experiments were conducted in two kinds of protected spaces, in a glasshouse and a plastic greenhouse, on experimental lots of the Institute for Vegetable Crops in Smederevska Palanka, Serbia. In the phase of technological maturity of lettuce, laboratory samples were taken. For preparing ethanol extracts of lettuce the fresh lettuce was used.

\section{Sample preparation}

Green leaves of the lettuce (samples) (20.0 g) were being extracted by $96 \%$ ethanol $(200.0 \mathrm{~mL})$ for $24 \mathrm{~h}$ in the process of cold maceration. The solutions have been filtrated after that time and ethanol was removed by a rotary evaporator (Devarot, Elektromedicina, Ljubljana, Slovenia) under a vacuum and was dried at 40 ${ }^{\circ} \mathrm{C}$. The dried extracts were stored in glass bottles at 4 ${ }^{\circ} \mathrm{C}$ to prevent oxidative damage untill analysis.

\section{Chemicals}

All chemicals and reagents were of analytical grade and were purchased from Sigma Chemical Co. (St. Louis, MO, USA), Alfa Aesar (Karlsruhe, Germany) and Aldrich Chemical Co. (Steinheim, Germany).

\section{Spectrophotometric measurements}

The spectrophotometric measurements were performed using an ultraviolet-visible spectrophotometer (model MA9523-SPEKOL 211, ISKRA, Horjul, Slovenia).

\section{Total phenols content}

Total phenols in the lettuce ethanolic extracts were estimated according to the Folin-Ciocalteu method [20]. The extract was diluted to the concentration of 1 $\mathrm{mg} / \mathrm{mL}$, and aliquots of $0.5 \mathrm{~mL}$ were mixed with $2.5 \mathrm{~mL}$ of Folin-Ciocalteu reagent (previously diluted 10-fold with distilled water) and $2 \mathrm{~mL}$ of $\mathrm{NaHCO}_{3}$ (7.5\%). Aliquots were left for $15 \mathrm{~min}$ at $45{ }^{\circ} \mathrm{C}$, and then the absorbance was measured at $765 \mathrm{~nm}$ with a spectrophotometer against a blank sample. Gallic acid (GA) was used to calculate the standard curve. The assays were carried out in triplicate; the results were the mean values \pm standard deviations and expressed as $\mathrm{mg}$ of gallic acid equivalents per gram of dry extract (mg of $\mathrm{GA} / \mathrm{g}$ ).

\section{Total flavonoids content}

The aluminium chloride colorimetric method [21] was used to measure the flavonoids content of the lettuce extracts. Two percent aluminium chloride $(0.5$ $\mathrm{mL}$ ) in methanol was mixed with the same volume of methanol solution of plant extract. After 1 hour-incubation at room temperature, the absorbance of the mixtures was measured at $415 \mathrm{~nm}$ using UV/Vis spectrophotometer. Rutin was used as standard for the calibration curve. Estimation of the total flavonoids was carried out in triplicate. The results were mean values \pm standard deviations and expressed as rutin equivalents (mg of RU/g of dry extract).

\section{Total antioxidant capacity}

The total antioxidant capacity of the three varieties of lettuce extracts was evaluated by the phosphomolybdenum method [22]. The assay is based on the reduction of $\mathrm{Mo}(\mathrm{VI})$ to $\mathrm{Mo}(\mathrm{V})$ by antioxidant compounds and subsequent formation of a green phosphate/Mo(V) complex at acid $\mathrm{pH}$. A total of $0.3 \mathrm{~mL}$ of sample extract was combined with $3 \mathrm{~mL}$ of reagent solution (0.6 M sulphuric acid, $28 \mathrm{mM}$ sodium phosphate and $4 \mathrm{mM}$ ammonium molybdate). The tubes containing the reaction solution were incubated at 95 ${ }^{\circ} \mathrm{C}$ for $90 \mathrm{~min}$. After cooling to room temperature the absorbance of the solution was measured at $695 \mathrm{~nm}$ with a spectrophotometer against methanol as the blank. Ascorbic acid (AA) was used as the standard, and total antioxidant capacity was expressed as micrograms of AA per gram of dry extract ( $\mu \mathrm{g} A \mathrm{~A} / \mathrm{g}$ dry extract). The experiment was performed in triplicate and the average absorption \pm standard deviation was used to express the total antioxidant capacity.

\section{2,2-Diphenyl-1-picrylhydrazyl free radical scavenging activity}

The capacity to scavenge the "stable" free radical DPPH was monitored according to the method of Takao et al. [23] adopted with suitable modifications from Kumarasamy et al. [24]. 2,2-Diphenyl-1-picrylhydrazyl (DPPH) $(8 \mathrm{mg})$ was dissolved in methanol $(100 \mathrm{~mL})$ to obtain a concentration of $80 \mu \mathrm{g} / \mathrm{mL}$. Serial dilutions were prepared with the stock solution $(1 \mathrm{mg} / \mathrm{mL})$ of the extract. Various concentrations of lettuce extract (2 $\mathrm{mL}$ ) were then mixed with $2 \mathrm{~mL}$ of methanolic solution containing DPPH and left for $30 \mathrm{~min}$ in the dark (until stable absorption values were obtained). The absorbance was measured at $517 \mathrm{~nm}$. Ascorbic acid (AA), gallic acid (GA), and butylated hydroxytoluene (BHT) 
were used as reference standards and were prepared by being dissolved in methanol to obtain the stock solution with the same concentration $(1 \mathrm{mg} / \mathrm{mL})$. The control sample was prepared containing the same volume without test compounds or reference antioxidants. The $95 \%$ methanol was used as a blank. The $50 \%$ inhibition concentration $\left(/ C_{50}\right)$ value, defined as the concentration of the test material that leads to $50 \%$ reduction of the free radical concentration, was calculated as micrograms per millilitre through a sigmoidal dose-response curve.

\section{Hydroxyl radical scavenging activity}

The ability of examined lettuce to inhibit a non-site specific hydroxyl radical-mediated peroxidation was carried out according to the method described by Hinneburg et al. [25]. The reaction mixture contained 100 $\mu \mathrm{L}$ of extract dissolved in water, $500 \mu \mathrm{L}$ of $5.6 \mathrm{mM}$ 2-deoxy-D-ribose in $\mathrm{KH}_{2} \mathrm{PO}_{4}-\mathrm{NaOH}$ buffer (50 mM, pH 7.4), $200 \mu \mathrm{L}$ of premixed $100 \mu \mathrm{M} \mathrm{FeCl}_{3}$ and $10^{4} \mathrm{mM}$ EDTA (1:1 V/V) solution, $100 \mu \mathrm{L}$ of $1.0 \mathrm{mM} \mathrm{H}_{2} \mathrm{O}_{2}$ and $100 \mu \mathrm{L}$ of $1.0 \mathrm{mM}$ aqueous $\mathrm{AA}$. Tubes were vortex-mixed and incubated at $50{ }^{\circ} \mathrm{C}$ for $30 \mathrm{~min}$. Then, $1 \mathrm{~mL}$ of $2.8 \%$ trichloroacetic acid and $1 \mathrm{~mL}$ of $1.0 \%$ thiobarbituric acid were added to each tube. The samples were vortexmixed and heated in a water bath at $50{ }^{\circ} \mathrm{C}$ for $30 \mathrm{~min}$. The extent of oxidation of 2-deoxyribose was estimated from the absorbance of the solution at $532 \mathrm{~nm}$. The percentage inhibition values were calculated from the absorbance of the control and of the sample, where the controls contained all the reaction reagents except the extract or positive control substance. The values are presented as the mean values of triplicate analyses.

\section{Ascorbic acid content}

Ascorbic acid was determined according to the method of Klein and Perry [26]. The dried ethanolic extract $(100 \mathrm{mg}$ ) was extracted with $10 \mathrm{ml}$ of $1 \%$ metaphosphoric acid for $45 \mathrm{~min}$ at room temperature and filtered through Whatman No. 4 filter paper. The filtrate $(1 \mathrm{ml})$ was mixed with $9 \mathrm{ml}$ of 2,6-dichlorophenolindophenol and the absorbance was measured within $30 \mathrm{~min}$ at $515 \mathrm{~nm}$ against a blank. The content of ascorbic acid was calculated on the basis of the calibration curve of standard I-ascorbic acid (0.020-0.12 $\mathrm{mg} / \mathrm{ml}$ ). The results were expressed as milligrams of ascorbic acid/100 $\mathrm{g}$ of fresh lettuce.

\section{$\beta$-Carotene and lycopene content}

$\beta$-Carotene and lycopene were determined according to the method of Nagata and Yamashita [27]. The dried ethanolic extract (100 $\mathrm{mg}$ ) was vigorously shaken with $10 \mathrm{ml}$ of acetone-hexane mixture (4:6) for $1 \mathrm{~min}$ and filtered through Whatman No. 4 filter paper. The absorbance of the filtrate was measured at 453, 505, 645 and $663 \mathrm{~nm}$. Contents of $\beta$-carotene and lycopene were calculated according to the following equations:

Lycopene $(\mathrm{mg} / 100 \mathrm{ml})=-0.0458 A_{663}+0,204 A_{645}+$ $+0.372 A_{505}-0.0806 A_{453}$

$\beta$-Carotene $(\mathrm{mg} / 100 \mathrm{ml})=0.216 A_{663}-1,22 A_{645}-$ $-0.304 A_{505}+0.452 A_{453}$

\section{Statistical analysis}

In order to determine the lowest possible significant differences among the researched parameters the one way ANOVA was applied.

\section{RESULTS AND DISCUSSION}

Table 1 shows the total phenols and flavonoids as well as the antioxidant activity of extracts of the examined lettuce varieties cultivated in the glasshouse and plastic greenhouse under controlled conditions.

Table 1. Total phenols, flavonoids, total antioxidant capacity and antioxidant activity of the lettuce extracts tested and standards

\begin{tabular}{|c|c|c|c|c|c|}
\hline \multirow[b]{2}{*}{ Sample plant } & \multirow{2}{*}{$\begin{array}{l}\text { Total phenols } \\
\text { mg GA/g }\end{array}$} & \multirow[b]{2}{*}{$\begin{array}{l}\text { Flavonoids } \\
\text { mg RU/g }\end{array}$} & \multirow{2}{*}{$\begin{array}{c}\text { Total antioxidant capacity } \\
\qquad \mu \mathrm{g} \mathrm{AA} / \mathrm{g}\end{array}$} & \multicolumn{2}{|c|}{$I_{50} / \mu \mathrm{g} \mathrm{ml}^{-1}$} \\
\hline & & & & $\begin{array}{c}\text { DPPH scavenging } \\
\text { activity }\end{array}$ & $\begin{array}{l}\text { Hydroxyl radical } \\
\text { scavenging activity }\end{array}$ \\
\hline Emerald $^{\mathrm{a}}$ & $75.88 \pm 0.54$ & $29.95 \pm 0.39$ & $69.50 \pm 1.00$ & $21.09 \pm 0.85$ & $90.98 \pm 0.97$ \\
\hline Emerald $^{b}$ & $68.87 \pm 0.55$ & $35.45 \pm 0.95$ & $68.99 \pm 0.67$ & $21.87 \pm 1.03$ & $89.67 \pm 0.97$ \\
\hline Vera $^{a}$ & $70.56 \pm 0.35$ & $34.65 \pm 0.89$ & $70.55 \pm 1.02$ & $25.45 \pm 1.05$ & $93.87 \pm 0.95$ \\
\hline Vera $^{\mathrm{b}}$ & $69.67 \pm 0.85$ & $34.23 \pm 0.89$ & $70.98 \pm 0.35$ & $24.57 \pm 0.95$ & $91.45 \pm 0.79$ \\
\hline Neva $^{a}$ & $78.98 \pm 0.67$ & $28.09 \pm 0.85$ & $70.15 \pm 0.54$ & $24.65 \pm 0.89$ & $87.56 \pm 1.05$ \\
\hline Neva ${ }^{b}$ & $73.67 \pm 0.67$ & $27.87 \pm 1.03$ & $69.95 \pm 0.35$ & $24.23 \pm 0.87$ & $91.67 \pm 0.85$ \\
\hline$L S D_{0.05}$ & 5.151 & 5.481 & 0.614 & 1.397 & 5.697 \\
\hline$L S D_{0.01}$ & 7.495 & 7.975 & 0.893 & 2.033 & 8.289 \\
\hline Gallic acid & - & - & - & $3.79 \pm 0.69$ & $59.14 \pm 1.10$ \\
\hline Ascorbic acid & - & - & - & $6.05 \pm 0.34$ & $160.55 \pm 2.31$ \\
\hline $\mathrm{BHT}$ & - & - & - & $15.61 \pm 1.26$ & $33.92 \pm 0.79$ \\
\hline
\end{tabular}

\footnotetext{
${ }^{a}$ Plastic greenhouse; ${ }^{b}$ glasshouse
} 
The table also displays $I C_{50}(\mu \mathrm{g} / \mathrm{ml})$ values of $D P P H$ scavenging activity and hydroxyl radical scavenging activity of the examined lettuce extracts and standards in relation to which these determinations were performed.

The results show that lettuce extracts have high content of total phenols and flavonoids, which has been established by other authors in case of other lettuce varieties [28]. The highest content of total phenols is in the lettuce variety Neva cultivated in the plastic greenhouse $(78.98 \pm 0.67 \mathrm{mg} \mathrm{GA} / \mathrm{g})$. If we compare the amounts of phenols in the plastic greenhouse lettuce, somewhat lower content of phenols that the Neva lettuce is in the variety named Emerald (75.88 \pm $\pm 0.54 \mathrm{mg} \mathrm{GA} / \mathrm{g}$ ), and the lowest is in the Vera lettuce $(70.56 \pm 0.35 \mathrm{mg} \mathrm{GA} / \mathrm{g})$ [13]. The lettuce cultivated in the glasshouse has lower concentrations of total phenols, but the variety Neva has the highest content of total phenols in these conditions as well $(73.67 \pm 0.67 \mathrm{mg}$ $\mathrm{GA} / \mathrm{g}$ ), whereas other two varieties cultivated in the glasshouse display a similar amount of total phenols [17]. The total content of phenols in the research does not represent the significant level of differences among the researched varieties. Significant difference has been found for the place of growth - that is - for the phenol content is significantly higher in lettuces grown in plastic houses comparing to glass-house production.

The lettuce Emerald from the glasshouse contains the highest amount of flavonoids $(35.45 \pm 0.95 \mathrm{mg}$ $\mathrm{RU} / \mathrm{g}$ ), and Neva from the glasshouse contains the lowest $(27.87 \pm 1.03 \mathrm{mg} \mathrm{RU} / \mathrm{g})$. It was established that there is a difference in the amount of flavonoids in these two varieties of lettuce if cultivated in different conditions, whereas in case of the lettuce Vera this difference is small. No significant difference of the flavonoid content has been found both among the varieties and among the place of growing (plastic- or glasshouse).

The presence of phenols and flavonoids points to the existence of an antioxidant activity of the biological system especially regarding their oxidation-reduction properties which play a significant role in the absorption and neutralization of free radicals, quenching of mono- and triplet-oxygen and dissolution of peroxides [29]. A significant property of flavonoids is their excellent radical scavenging ability, which enables therapeutic use [30]. The results have shown that ethanolic extracts of the examined lettuce varieties possess an antioxidant activity with total antioxidant capacity ranging from $70.98 \pm 0.35 \mu \mathrm{g} A / g$ in the lettuce Vera cultivated in the glasshouse to $68.99 \pm 0.67 \mu \mathrm{g} \mathrm{AA} / \mathrm{g}$ in the lettuce Emerald from the glasshouse (Table 1). Antioxidant capacity of the lettuce extracts of different varieties cultivated in glasshouses and plastic greenhouses do not differ one from another to a great extent, which was expected since they belong to the same type of lettuce, while the research with different lettuce varieties showed great differences in anti-oxidative activity [17]. Differences among the varieties for the total oxidative capacity for the variety are at the significant level ( $p \leq 0.01$ ), while the place of growth was without statistical significance.

$I C_{50}$ values were determined for each lettuce extract (Table 1). The extract of the Emerald lettuce cultivated in the plastic greenhouse has better antioxidant properties (lower $I C_{50}$ DPPH values) than the other lettuce varieties' extracts. For this parameter, a highly significant difference at the level of variety was found, which represents highly determinated genotype, while the place of growth was not significant.

The content of $\mathrm{L}$-ascorbic acid, $\beta$-carotene and lycopene is presented graphically (Figure 1).

The highest content of I-ascorbic acid is found in the extract of the Neva lettuce cultivated in the glasshouse (10.9 $\mathrm{mg} / 100 \mathrm{~g}$ fresh lettuce), and the lowest in the extract of the Emerald lettuce cultivated in the plastic greenhouse $(7.3 \mathrm{mg} / 100 \mathrm{~g}$ fresh lettuce). It has been observed that the lettuce produced in the glasshouse contains a somewhat higher content of I-ascorbic acid. Accoriding to some researches $[18,19]$, the quantity of L-ascorbic acid depends upon lettuce genotype, but it can be increased by increasing the light intensity. As the light intensity is greater in a glasshouse than in a plastic greenhouse, the lettuce cultivated in glasshouses has a somewhat higher content of L-ascorbic acid.

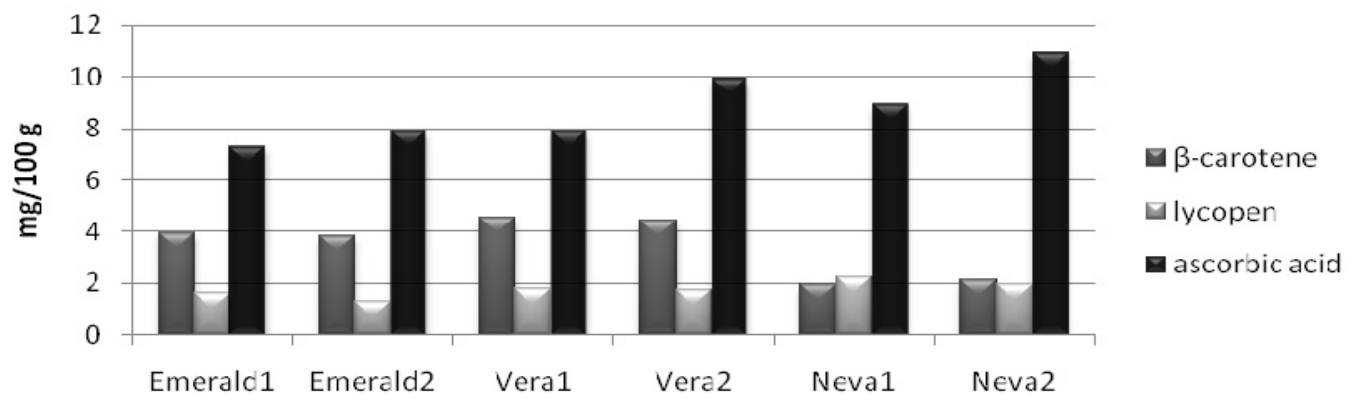

Figure 1. $\beta$-Carotene, lycopene and L-ascorbic acid concentrations ( $\mathrm{mg} / 100 \mathrm{~g}$ fresh lettuce) of three lettuce varieties; 1- plastic greenhouse and 2-glasshouse cultivated plants. 
The extracts of examined lettuce contain a smaller amount of $\beta$-carotene; the greatest amount of it is in the Vera lettuce $(4.35 \mathrm{mg} / 100 \mathrm{~g}$ fresh lettuce), and the smallest in the Neva lettuce $(1.97 \mathrm{mg} / 100 \mathrm{~g}$ fresh lettuce). It has been determined that the lettuce extracts contain vestigial amounts of lycopene; from $1.32 \mathrm{mg} /$ $/ 100 \mathrm{~g}$ fresh lettuce in the Emerald lettuce to $2.22 \mathrm{mg} /$ $/ 100 \mathrm{~g}$ fresh lettuce of the Neva variety. The values determined in the stated lettuce (L-ascorbic acid, $\beta$-carotene and lycopene) are in accordance with the data obtained by other authors [17,31-33].

\section{CONCLUSION}

The presented research of the content of the antioxidant components (total phenols, flavonoids, L-ascorbic acid, $\beta$-carotene and lycopene) and the antioxidant activity of the three lettuce varieties confirmed the values of lettuce in everyday nutrition. On the basis of the obtained results it could be concluded that none of the three examined lettuce varieties (Emerald, Vera and Neva) could be singled out as the one containing all the antioxidant components in the highest amount. Thus the Neva lettuce has the highest content of total phenols, L-ascorbic acid and lycopene, whereas the Emerald lettuce contains the greatest amount of flavonoids, and the Vera lettuce has the highest content of $\beta$-carotene. All three varieties of the examined lettuce display a solid antioxidant activity and are rather rich in phenolic compounds. Since the cultivation conditions were the same for all the examined lettuce varieties, it can be concluded that the content of antioxidant components (total phenols, flavonoids, $\beta$-carotene and lycopene) depends on the lettuce genotype. However, the content of L-ascorbic acid also depends on the light, which proved to be correct in this research as well, so that the lettuce cultivated in a glasshouse has a somewhat greater content of I-ascorbic acid.

\section{Acknowledgements}

This study is part of the TR 31059 project entitled: "A new concept in breeding vegetable cultivars and hybrids designed for sustainable growing systems using biotechnological methods"; financially supported by the Ministry of Education, Science and Technological Development of the Republic of Serbia.

\section{REFERENCES}

[1] S.D. Aust, B.A. Sringen, Free radicals in biology, Academic Press, New York, 1982, pp. 98-163.

[2] W.A. Pryor, J.W. Lightsey, D.G. Prier, The production of free radicals in vivo from the action of xenobiotics: the initiation of autooxidation of polyunsaturated fatty acids by nitrogen dioxide and ozone. In Lipid peroxides in Biology and Medicine, Academic Press, New York, 1982, pp. 1-22.

[3] J. Torel, J. Cillard, P. Cillard, Antioxidant activity of flavonoids and reactivity with peroxy radical, Phytochemistry 2 (1986) 383-385.

[4] W. Bors, M. Saran, Radical scavenging by flavonoid antioxidants, F.R.A. 2 (1987) 289-294.

[5] F. Visioli, G. Bellomo, C. Galli,. Free-radical-scavenging properties of olive oil polyphenols, B.B.R.C. 247 (1998) 60-64.

[6] F. Visioli, S. Bellosta, C. Galli, Oleuropein, the bitter principle of olives enhances nitric oxide production by mouse macrophages, Life Sci. 62 (1998) 541-546.

[7] J. Pokorny, Introduction, in: J. Pokorny, N. Yanishlieva, M.H. Gordon (Eds.), Antioxidants in food: practical applications. Woodhead Publishing Limited, Cambridge, 2001, pp. 1-30.

[8] A. Keys, Mediterranean diet and public health personal reflection, Am. J. Clin. Nutrit. 61 (1995) 1321S-1323S.

[9] L. Lipworth, M.E. Martinez, J. Angell, C.C. Hsien, D. Trichopoulos, Olive oil and human cancer: an assessment of evidence, Preven. Med. 26 (1997) 181-190.

[10] N.S. Fukushima, H. Tsuda, Carcinogenity and modification of the carcinogenic response by BHA, BHT and other antioxidants, Crit. Rev. Toxicol. 15 (1985) 109-150 .

[11] W.L. Stone, I. Leclair, T. Ponder, G. Bagss, B. Barret-Reis, Infants discriminate between natural and synthetic vitamin E, Am. J. Clin. Nutrit. 77 (2003) 899-906.

[12] B. Halliwell, J.M.C. Gutteridge, Free radicals in biology and medicine, $4^{\text {th }}$ ed., Oxford University Press Inc., New York, 2007.

[13] M. Skerget, P. Kotnik, M. Hadolin, A.R. Hras, M. Simonic, Z. Knez, Phenols, proanthocyanidins, flavones and flavonols in some plant materials and their antioxidant activities, Food Chem. 89 (2005) 191-198.

[14] A.T. Diplock, J.L. Charleux, G. Crozier-willi, F.J. Kok, C. Rice-Evan, M. Roberfroid, Functional food science and defence against reactive oxidative species, B. J. N. $80 \mathrm{~S}$ (1998) S77-S112.

[15] F.B. Hu, Dietary pattern analysis: a new direction in nutritional epidemiology, Curr. Opin. Lipidol. 13 (2000) 3-9.

[16] S. Dupont, Z. Mondi, G. Willamson, K. Price, Effect of variety, processing, and storage on the flavonoid glycoside and composition of lettuce and chicory, J. Agric. Food Chem. 48 (2000) 3957-3964.

[17] R. Llorach, A. Martinez-Sanchez, F.A. Tomas-Barberan, Characterisation of polyphenols and antioxidant properties of five lettuce varieties and ascarole, Food Chem., A 108 (2008) 1028-1038.

[18] B. Mou, Genetic variation of Beta-carotene and lutein contents in lettuce, J. Am.Soc. Hort. Sci. 130 (2005) 870$-876$.

[19] USDA 2005b, USDA, National Nutrient Database for Standard Reference, Release 18, Nutrient Data Laboratory Home Page, http://www.nal.usda.gov/fnic/ foodcomp, cited 2006. 
[20] V. Singleton, R. Orthofer, R.M. Lamuela-Raventos, Analysis of total phenols and other oxidation substrates and antioxidants by means of Folin-Ciocalteu reagent, Methods Enzymol. 299 (1999) 152-175.

[21] I.M.C. Brighente, M. Dias, L.G. Verdi, M.G. Pizzolatti, Antioxidant activity and total phenolic content of some Brazilian species, Pharm. Biol. 45 (2007) 156-161.

[22] P. Prieto, M. Pineda, M. Aguilar, Spectrophotometric quantitation of antioxidant capacity through the formation of a phosphomolybdenum complex: specific application to the determination of vitamin E, Anal. Biochem. 269 (1999) 337-341.

[23] T. Takao, N. Watanabe, I. Yagi, K. Sakata, A simple screening method for antioxidants and isolation of several antioxidants produced by marine bacteria from fish and shellfish, Biosci. Biotechnol. Biochem. 58 (1994) 1780-1783.

[24] Y. Kumarasamy, M. Byres, P.J. Cox, M. Jaspars, L. Nahar, S.D. Sarker, Screening seeds of some Scottish plants for free-radical scavenging activity, Phytother. Res. 21 (2007) 615-621.

[25] I. Hinneburg, H.J.D. Dorman, R. Hiltunen, Antioxidant activities of extracts from selected culinary herbs and spices, Food Chem. 97 (2006) 122-129.

[26] B. P. Klein, A. K. Perry, Ascorbic acid and vitamin A activity in selected vegetables from different geographical areas of the United States, J. Food Sci. 47 (1982) 941-945.
[27] M. Nagata, and I. Yamashita, Simple method for simultaneous determination of chlorophyll and carotenoids in tomato fruit, J. Food Sci. Technol. 39 (1992) 925-928.

[28] U. Hohl, B. Neubert, P. Holger, I. Schonhof, H. Böhm, Flavonoid concentrations in the inner leaves of head lettuce genotypes, Eur. Food Res. Technol. 213 (2001) 205-211.

[29] M.R. Saha, S.M.R. Hasan, R. Akter, M.M. Hossain, M.S. Alam, M.A. Alam, M.E.H. Mazumder, In vitro free radical scavenging activity of methanol extract of the leaves of Mimusops elengi, Linn. Bangladesh J. Vet. Med. 6 (2008) 197-202.

[30] B.H. Havsteen, The biochemistry and medical significance of the flavonoids, Pharmacol. Ther. 96 (2002) 67$-202$.

[31] C. Nicolle, N. Cardinault, E. Gueux, L. Jaffrelo, E. Rock, A. Mazur, Health effect of vegetable-based diet: Lettuce consumption improves cholesterol metabolism and antioxidant status in the rat, Clin. Nut. 23 (2004) 605-614.

[32] T. Bahorun, A. Luximon-Ramma, A. Crozier, O.I. Aruoma, Total phenol, flavonoid, proanthocyanidin and vitamin C levels and antioxidant activities of Mauritiam vegetables, J. Sci. Food Agric. 84 (2004) 1553-1561.

[33] Y.T. Szeto, T.C. Kwok, I.F. Benzie, Effects of a long-term vegetarian diet on biomarkers of antioxidant status and cardiovascular disease risk, Nutrition 20 (2004) 863$-866$.

\section{IZVOD}

\section{ANTIOKSIDATIVNI KAPACITET I SADRŽAJ FENOLA, ASKORBINSKE KISELINE, $\beta$-KAROTENA I LIKOPENA U SALATI}

Jasmina M. Zdravković ${ }^{1}$, Gordana S. Aćamović-Djoković ${ }^{2}$, Jelena D. Mladenović ${ }^{2}$, Radoš M. Pavlović Milan S. Zdravković ${ }^{1}$

${ }^{1}$ Institut za povrtarstvo, Smederevska Palanka, Srbija

${ }^{2}$ Agronomski fakultet, Univerzitet u Kragujevcu, Čačak, Srbija

(Naučni rad)

Određena je antioksidativna aktivnost tri sorte salate (Lactuca sativa L.) Emerald, Vera i Neva gajene u dve vrste zaštićenog prostora stakleniku i plasteniku pri kontrolisanim uslovima. Sadržaji antioksidativnih komponenti: ukupni fenoli, flavonoidi, L-askorbinska kiselina, $\beta$-karoten i likopen, određeni su u etanolskim ekstraktima salata spektrofotometrijskim metodama. Dobijeno je da najveći sadržaj ukupnih fenola (78,98 $\pm 0,67 \mathrm{mg} \mathrm{GAE} / \mathrm{g}$ suvog ekstrakta) ima etanolski ekstrakt salate sorte Neva gajene u plasteniku, dok salata Emerald gajena u stakleniku ima

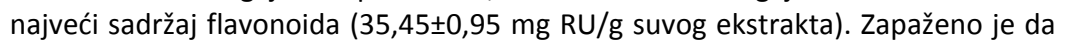
salate gajene u stakleniku imaju nešto veći sadržaj L-askorbinske kiseline od salate istih sorti iz plastenika. Sadržaj likopena $u$ ispitivanim salatama je zanemarljiv, a $\beta$-karotena je nizak. S druge strane visok sadržaj fenolnih komponenti uzrokuju dobre antioksidativne osobine nađene u svim sortama ispitivanih salata.
Ključne reči: Salata • Antioksidans • Fenoli • Askorbinska kiselina • Beta-karoten $\bullet$ Likopen 